\title{
Environmental and Health Impacts of Electronic Waste: A Global Concern!!
}

\section{ANUJA PRABHAKAR ${ }^{1}$, ROMI NAYYAR*2, PK SHARMA³}

Electronic waste, commonly referred to as e-waste, is waste generated from discarded waste from an alarming number of electronic components which contains toxic substances affecting human health and the environment across the globe. In India, it is of extreme significance as its huge production uses more electronic materials and thus, dumps a significant amount of e-waste simultaneously. India is still lacking suitable infrastructure and methods is proper recycling and disposal. This review is an overview of current scenario in the developing countries like India depicting the magnitude of environmental and health hazards associated with improper recycling and disposal methods.

KEYWORDS: Health, Cadmium, Immune System

\section{INTRODUCTION}

Rapid urbanization and increased demand are two main factors propelling the electronic and electrical equipment manufacturing industry as a dominant producer across the globe. ${ }^{1}$ In India, the Information and Technology (I\&T) sector has been a significant contributor to the growing economy. ${ }^{2}$ With the world undergoing a digital revolution, electronic gadgets and equipments have invaded every single human life, providing them more comfort, security with acquisition and exchange of information. ${ }^{3}$ Such expansion comes with a caveat though: this technology addicted generation is creating its own toxic footprints in the form of e-waste.

\section{E-WASTE: SOURCES AND CATEGORIES}

E-waste is described as "any electronic appliances which are termed as old, end of life devices such as laptops and computers, television sets, mobile phones/smart phones, DVD players etc. which are discarded by their users due to any malfunction or after nearing the end of their life cycle". ${ }^{4}$

A few of the e-waste sources are laptops, router devices, scanners, printers, televisions, mobile phones, fridge, washing machines, microwaves, gaming consoles, tubelights, bulbs, LED lights, remote controls, toys, speakers, ECG machine, ultrasound machines, $\mathrm{x}$-ray, card swiping machine etc.

Generation of e-waste is divided among categories which include: (i) Household appliances large in size, (refrigerators, washing machines, etc), (ii) communication and information technology (smartphones/laptop, etc) and (iii) consumer equipment (television sets, etc).

\section{E-WASTE AND ITS COMPOSITION}

The discarded e-waste has many components categorized into identifiable and/or removable. A few examples include metal, compressor / motor, glass, displays, rubber, concrete, wiring, circuit board, textile, fluorescent lamp(s), heating element, incandescent lamp and so on. This e-waste can be further elaborated as hazardous and non -hazardous. Examples of generated hazardous waste includes elements like mercury, lead, arsenic, hexavalent chromium, selenium and cadmium. ${ }^{5}$

\section{E-WASTE AND ITS GENERATION}

The following are the main reasons on the generation of e-waste:

- Research and advancement in technology

- Lifestyle changes

- Limited usage

The absence of strict policies in India put a hurdle in the management of E-waste. The unofficial sector uses primitive methods of waste disposal and recycling which includes overtly blazing the waste followed by exposing them to acid for retrieving precious metals and then throw the undesired waste into landfills. Due to the lack of any protective equipment, labourer in the unstructured e-waste management make themselves prone to high risk and unsafe consequences.

As a result of such practices, hazardous metals present 
in the e-waste get accumulated into the soil and water or convert into toxic emissions that are released into the air with disastrous health outcomes on human and environmental health.

\section{E- WASTE AND ITS HAZARDS}

General health and environment are very prone because of improper management of e-waste. Toxins produced such as furans and dioxins from PVC, mercury, beryllium, cadmium, lead, etc are passed into the environment and cause the following risk to health:

- Issues related to reproduction \& development

- Impairment of immune system and nervous system

- Hormonal changes

- Kidney damage

- Cancer of the lung

- Beryllium disease (Chronic)

- Skin ailments

- Cadmium accumulation in liver and kidney (including kidney damage)

- Asthmatic bronchitis

- Damage to DNA

- Weakness in muscles

\section{E-WASTE \& ITS IMPACT ON GENERAL HEALTH} AND ENVIRONMENT

E-waste is an amalgamation of multiple components which contain harmful substances which lead to deleterious effect on health and the environment. These problems arise due to the improper management of these hazardous components. ${ }^{6}$ It can have serious implications for the surroundings where e-waste is disposed or recycled. Electronics contains highly noxious chemicals like mercury, cadmium, lead, beryllium and phosphor compounds. ${ }^{3}$

\section{VARIOUS HARMFUL PRODUCTS OF E-WASTE}

Lead: Its adverse effects are mainly seen in the central nervous system, hemopoietic system, reproductive system, genitourinary system and peripheral nervous system and impair one's standard of living. ${ }^{7}$

Mercury: Its common undesirable health impact includes damage in the genito-urinary system, Central Nervous system, peripheral nervous system with the ability to affect the developing foetus. The inorganic mercury dispersed in water changes into methylated mercury which is taken up fishes which is then consumed by humans and affects overall health.,5,7,
Cadmium: Cadmium is a long-term snowballing poison and congregates in kidneys. Cadmium along with beryllium has been found to have carcinogenic potential.9,10

PAH (Polycyclic Aromatic Hydrocarbons): This chemical compound exerts a deleterious effect on our urinary bladder, skin and lungs. The link between skin and lung cancers has been established in various studies. ${ }^{9,10}$

\section{GLOBAL SCENARIO}

Rapid Advancement in the field of research and technology in the $18^{\text {th }}$ century brought about the industrial revolution which pronounced a new era in human society. In the $2 \mathrm{O}^{\text {th }}$ century, evolving technological methods have enhanced the quality of human life, however, on the flip side, has led to an array of problems both for the environment and one's health. Globally around huge tons of e-waste in the range of approximately 50 million tonnes are produced annually. The leading e-waste generator is USA, which discards 3 million tonnes every year followed by China with disposal of 2.3 million tons of e-waste. ${ }^{9}$

\section{E-WASTE AND THE INDIAN SCENARIO}

India was reported to be the 2nd largest producer of Ewaste in Asia and generates approximately 3,30,000 tonnes of E-waste in a year. ${ }^{11}$ The collection and recycling of such wastes in the country is taken care of by the informal sector at present, due to which, the government of India took an initiative enhancing awareness about safe management of electronic waste. Regulation of e-waste comes under the ambit of the Ministry of Environment, Forests, and Climate Change (MoEFCC). In addition, the Central Pollution Control Board ( $\mathrm{CPCB}$ ), and the State Pollution Control Board (SPCB) is implementing procedures set forth by the MoEFCC for safe e-waste disposal. Other Organizations in India include, but are not limited to: Knowledge bank for e-waste management in India, The E-waste Guide, India (www.ewaste.in), National Solid Waste Association of India (NSWAI) (www.nswai.com), Toxics Link (www.toxicslink.org) and tEP Workweb, WEEE Forum, Clean India, Indian Environmental Society, INDIA and Microbial Biotechnology Area of Tata Energy Research Institute. $^{12}$

\section{DRIVERS AND CHALLENGES ${ }^{15}$}

The challenges faced in the management of e-waste by 
the society can be seen mainly as to reduce the burden of e-waste, reduce exposure to workers and community, improve the collection system as well as the legal frame work and to prevent the leaching of heavy metals from land fills and incinerators.

In the absence of reliable data present for assessing the volume of e-waste generated in the country, manufacturing companies and users are even not aware of correct e-waste disposal/hazards and there is no available estimation of the e-waste being recycled and generated in India.

E-waste is mostly processed by the informal sector using elementary techniques like open-air burning, acid leaching causing damage to the environment and little or no knowledge of toxins within the workers makes them exposed to health hazards. In addition, open backyard recycling impacts nearby residents and immigrant labourers.

Inefficient recycling procedures lead to loss of substantial material(s) as recyclers who recover precious metals (gold, platinum, silver, copper, etc) improperly dispose of the rest in the absence of any specific law for the management of e-waste.

\section{E-WASTE TREATMENT AND DISPOSAL METHODS $^{14}$}

1. Incineration: It is complete combustion of waste material at high temperature $\left(900-1000^{\circ} \mathrm{C}\right)$. Its major advantage is that it reduces the e-waste volume, there is a maximum utilization of inflammable substances and dangerous organic matters are converted into less toxic products. On the other hand, its disadvantages include release of a large amount of residual gas and significant emission of cadmium and mercury.

2. Recycling: Recycling of various e-waste can be done after dis-assembly of different components and removal of toxic and non-working components.

3. Re-Use: Re-use of working equipment/ components shall help in reducing the global e-waste load.

4. Landfilling: It is a widely used method of e-waste disposal. Landfilling trenches uses the technique of burying e-waste by a thick layer of soil. In new-age techniques, an impervious layer of clay or plastic and the extracts are collected and carried to wastewater treatment plant. However, it is not considered as a safe method as it leads to leaching of toxic materials underground and causes water and soil contamination. ${ }^{15-17}$

\section{CONCLUSION}

E-waste should be reused, recycled and disposed in a safe and a standardized manner. When not refurbished, it should be disassembled by well compensated, trained and protected workers with advanced e- waste recycling facilities and technologies. An acceptable risk threshold should be marked different for children and adults and efficiently eliminating the presence of toxic components completely is important. At last there should be policies to be implemented with research needs, education and awareness programs in countries like India.

\section{REFERENCES}

1. Ramesh B, Kuber A, Ahmed C. Electrical and electronic waste: a global environmental problem. Waste Management \& Research. 2007;25(4):307-18. https://doi.org/10.1177/0734242X07076941

2. India Brand Equity Foundation. IT \& BPM Industry in India (Online Article). Available from: https://www.ibef.org/industry/information-

technology-india.aspx. [Last accessed on $15^{\text {th }}$ March 2021]

3. Sinha S. Downside of the Digital Revolution. Toxics Link (2007). (Online Article). Available at: http://www. toxicslink.org. [Last accessed on $15^{\text {th }}$ March, 2021]

4. eWaste Guide. Available from: http://www.ewaste.in. [Last accessed on $15^{\text {th }}$ March, 2021]

5. Central Pollution Control Board (CPCB). (Electronic Waste (Online Article). Available from: http://www.cpcb.nic.in [Last accessed on $15^{\text {th }}$ March 2021]

6. E-waste in India. Research unit (Larrdis) Rajya Sabha secretariat New Delhi June, 2011 (Online Article). Available at: rajyasabha.nic.in/rsnew/publication electronic/EWaste in india.pdf. [Last accessed on $15^{\text {th }}$ March 2021] 7. Harrington JM, Aw TC, Baker EL. Occupational and environmental health and safety. In: David AW, Timothy MC, John DF, Edward JB, editors. Oxford Textbook of Medicine. 4 th ed. Vol. 1. New York: Oxford University Press; 2003. pp. 956-6o. Chap.8.4.1.

8. $\mathrm{Hu} \mathrm{H}$, Speizer FE. Specific environmental and occupational hazards. In: Braunwald E, Fausi AS, Kasper DL, et al., editors. Harrison's Principles of Internal Medicine. 15th edition. Vol 2. McGraw-Hill Inc; 2001. pp. 2591-2. Part 15, Section1.395. 
9. Strickland PT, Kensler TW. Chemical and physical agents in our environment. In: Abeloff MD, Armitage JO, Lichter AS, Niederhuber JE, editors. Clinical oncology. 1st ed. Churchill Livingston Inc.; 1995. pp. 153-16o. Part 1, Section 2

10. Stewart BW, Kliehues P. World Cancer Report. Lyon: IARC Press; 2003

11. Devika R. E-waste management. Elysium Journal Of Engineering And Research 2014; 1(1): 22-3.

12. Times of India. Imported E-waste seized by customs officials. (Online Article). Available from: https://timesofindia.indiatimes.com/home/environme nt/pollution/imported-e-waste-seized-by-customsofficials/articleshow/6381703.cms. [Last accessed on $15^{\text {th }}$ March 2021]
13. E-waste. Indian perspective. (Online Article). Available

at: http://www.nswai.com/images/newsletters/nov2007.p df. [Last accessed on $17^{\text {th }}$ March 2021]

14. Badoni P. E-waste Management In India. (Online Article). Available at: https://electronicsforu.com/technology-trends/ewastemanagement-india/2. [Last accessed on $17^{\text {th }}$ March 2021]

15. Scrapping the hi-tech myth: Computer waste in India. Published in Toxics Link. (Online Article). Available at: $\quad$ http://www.toxicslink.org/pubview.php?pubnum $=37$. [Last accessed on $17^{\text {th }}$ March 2021]
Cite this article as:

Prabhakar A, Nayyar R, Sharma PK. Environmental and Health Impacts of Electronic Waste: A Global Concern!!. Int Healthc Res J. 2021;5(4):RV1-RV4.

Source of support: Nil, Conflict of interest: None declared
https://doi.org/10.26440/IHRJ/0505.08445 